\title{
Improving Corporate Venture Investment through Strategic Inter-Firms Knowledge Transfer: An Empirical Evaluation of Service Firms in Nigeria
}

\author{
Sunday Alewo Omale ${ }^{1}$, Marcus Garvey Orji ${ }^{1}$, Thomas Oladele ${ }^{1}$, Kizito Babatunde Olaniyi ${ }^{2}$ \\ ${ }^{1}$ Department of Business Administration, Veritas University, Abuja, Nigeria \\ ${ }^{2}$ Department of Entrepreneurial Studies, Veritas University, Abuja, Nigeria
}

Email address:

drsaomale@gmail.com (S. A. Omale),orjimarcusgarvey@yahoo.com (M. G. Orji)

To cite this article:

Sunday Alewo Omale, Marcus Garvey Orji, Thomas Oladele, Kizito Babatunde Olaniyi. Improving Corporate Venture Investment Through Strategic Inter-Firms Knowledge Transfer: An Empirical Evaluation of Service Firms in Nigeria. Journal of Investment and Management. Vol. 6, No. 1, 2017, pp. 44-49. doi: 10.11648/j.jim.20170601.17

Received: December 18, 2016; Accepted: January 17, 2017; Published: March 4, 2017

\begin{abstract}
This study examines corporate venture investment performance through strategic inter-firms knowledge transfer: An Empirical Evaluation of Service Firms in Nigeria. Inter-firm knowledge transfer has reward over traditional markets because firm-specific technological capabilities frequently are based on implied knowledge and are subject to considerable doubt regarding their uniqueness and performance. Inter-firm knowledge transfer enables one firm to gain access to key knowledge based capabilities of another without necessarily acquiring that capability. Two research objectives, research questions and hypotheses were formulated respectively in carrying out this inquiry. Data relevant to the study were reviewed using secondary method of data collection while the chief instrument for analytical data collection was questionnaire, which was designed for selected management employees. A sample of 216 employees of service firms in Nigerian pharmaceutical, banking, electrical and general service firms was used to test the framework. The data was analyzed using students ' $t$ ' distribution test method. The result of the study showed that strategic inter-firms knowledge transfer impact positively on corporate venture performance. It enables one firm to gain access to key knowledge based capabilities of another without necessarily acquiring that capability. When we examine corporate venture investment through strategic inter-firms knowledge transfer one will certainly conclude that, the primary objective of conducting knowledge transfer activities is to retain and manage various knowledge types that can be used to inform decision making and problem solving. Finally, it was recommended that, Firms should identify the knowledge holders within their organization and motivating them to share their knowledge to enhance it investment and performance.
\end{abstract}

Keywords: Corporate Venture, Investment, Strategy, Inter-Firm Knowledge Transfer, Service Firms

\section{Introduction}

Reasons have been advanced for the creation of corporate venture investment with the help of inter-firm knowledge transfer. Superior corporate venture investment, growth costs, perceived decline in product life-cycles, political changes, economic meltdown and risks involved in conducting business transaction necessitated the need for corporate venture investment through inter-firm knowledge transfer.

The need to spread the risks and cost of innovation, as capital requirements for development projects in industries such as pharmaceuticals, telecommunications and commercial aircraft have risen (Mowery et al) [1]. Quick infiltration of foreign markets is more vital than ever in many knowledge driven industries in view of the need to remain competitive and improve collaboration which might be achieved easily through inter-firm knowledge transfer.

For instance, strategic motives play a role in alliances that are formed to facilitate strategic coordination among competitors to increase market power (Porter \& Fuller [2] Hagedoorn, [3]. The acquisition of new technical skills or technological capabilities from partner firms is one of the most widely cited motives for collaboration (Powell \& Brantley) [4]. 
Inter-firm knowledge transfer has advantages over traditional markets because firm-specific technological capabilities frequently are based on implied knowledge and are subject to considerable doubt concerning their uniqueness and performance. Inter-firm knowledge transfer enables one firm to gain access to key knowledge based capabilities of another without necessarily acquiring that capability.

Mowery [1] maintain that, these features make it difficult to draft simple contracts governing the sale or licensing of such capabilities. Grant and Baden-Fuller, (1995) argues that in an alliance in which one firm designs and the other manufactures an advanced semiconductor device. Among these alliances, inter-firm knowledge transfer may be limited to only the codified information necessary to coordinate otherwise separable activities that draw on different knowledge domains.

Needs of the users, peculiarity of firms, decision-making techniques or management systems, complex networks for handling the marketing and distribution of products and knowledge of specific markets accelerate the desire for interfirm knowledge transfer for improve performance and efficient corporate venture investment. It is against this background that the researchers seeks to examine how corporate venture investment can be improved through strategic inter-firms knowledge transfer: An Empirical Evaluation of Service Firms in Nigeria.

\subsection{Statement of the Problem}

Research has shown that at least four major external environments are catalysts for organization success or failure: political, economic, culture, regulation and technology. Effective management requires that organizations anticipate and adjust to these external environmental factors. Recent recession in the Nigeria economy has been a proof of this- many companies are surviving the recession period by adopt diverse strategies in order to achieve its objectives. Many corporate companies responded to the current economic recession by reducing employment, investment and debt, and adopt differentiation strategies according to Tansey, Meng and Cleland [5].

Unfortunately, while some corporate companies have used some of these survival strategies to achieve success through making profit, some have found it difficult to manage the impact of economic recession. Even some of these corporate companies that have declared profit efficiency at a point, still experience difficult situation and hence shortfall in profit. For instance, despite the tough economic environment, Nestle Nigeria who had experience increased revenue by 22 per cent in the first half of 2016 reported a 94 per cent fall in profit after tax for the second half-year 2016 (Thisday Newspaper) [6]. This implies that companies that have the knowledge to adapt successfully to changing business environment at a point may find it difficult in another point.

The inability of corporate companies to continuously learn how to adapt to changing business environment has caused corporate companies to continue to lose profit, achieve low market share, inability to leverage technology, become short of ways to repel competitive and in worse scenarios such company's survival could be threatened. It is against these aforementioned problems that this study seeks to examine the effect of Inter-firms knowledge transfer on corporate venture performance in Nigeria service firms

\subsection{Research Questions}

Choosing a research question is central to both quantitative and qualitative investigation and in some cases it may come first before building theoretical structure for the study. Consequently, the following research questions are offered for investigation.

1. To what degree does strategic inter-firms knowledge transfer improve corporate venture performance?

2. To what extent does corporate venture investment speed up economic development of Nigeria?

\subsection{Objectives of the Study}

The wide aim of this study is investigate the degree to which improved corporate venture investment can be achieved through strategic inter-firms knowledge transfer using selected service firms in Nigeria for the survey.

Particularly, the study seeks to:

1. Determine the extent to which strategic inter-firms knowledge transfer improves corporate venture performance?

2. Find out whether corporate venture investment speeds up economic development of Nigeria?

\subsection{Research Hypotheses}

A hypothesis is unsure declaration about the connection among two or more variables. It is a proposal made as a basis for reasoning without any postulation of its fact. Thus, the following hypotheses are presented.

1. Strategic inter-firms knowledge transfer impact positively on corporate venture performance.

2. Corporate venture investment speeds up economic development of Nigeria.

\section{Literature Review}

Argote and Ingram [7] define knowledge transfer as "the process through which one unit (e.g., group, department, or division) is affected by the experience of another". They further point out that the transfer of organizational knowledge (i.e., routine or best practices) can be observed through changes in the knowledge or performance of recipient units.

There is growing acknowledgment that many strategic resources and new sources of knowledge lie beyond the traditional boundaries of the firm. Large body of empirical research suggests that one of the most frequent and important sources of new knowledge are a firm's suppliers. [7] New knowledge from suppliers can bring a number of benefits to the firm, such as enabling individuals to learn from best practice, increasing the stock of knowledge held within the firm, speeding up the process of corporate venture investment, and promoting the development of new products. 
Inter-firm knowledge transfer can be vita source of corporate venture investment and competitive advantage. Firms can draw on their supplier's knowledge to improve product development activities, with collaborative relationships helping overcome the difficulties of transferring knowledge across inter-organizational boundaries. While inter-firm knowledge transfers are central to the success of corporate venture investment (CVI), transferring this information is complex to achieve. Determining the best way of utilizing knowledge initially dispersed among all people is means for sustainable corporate investment.

Evidence that venture capitalists also transfer valuable non-patented knowledge is presented by Pahnke et al. [8] based on interviews with entrepreneurs, venture capitalists and industry experts. There is, moreover, indirect evidence, highlighting the importance of knowledge transfer in other, similar settings. Helmers et al. [9] opined that information transmission through interlocking boards of directors has a significant positive effect on innovation. [10]

In a business environment that contains multiple pools of specialist knowledge, firms develop a competitive advantage by generating new knowledge through internal $R \& D$, and by being more capable at integrating knowledge from external sources [11].

Proof suggests that firms that are able to transfer knowledge effectively are more likely to survive and generate a competitive advantage, compared to those firms that are less adept at knowledge transfer [7].

Integrating supplier's into the firm's activities and the transfer of knowledge across organizational boundaries is vital to the success of the firm and its products (Handfield et al., 1999; Ragatz et al., 1997). Research on inter-firm knowledge transfer has identified a number of different determinants including the motivation [11].

\subsection{Inspiration of Knowledge Transfer}

Knowledge transfer maintain and promotes the sharing of thoughts, experiences, skills and learning's to assist and control individual or group decision making in an organization. Knowledge transfer is the realistic way of transferring knowledge from one part of the organization to another that seeks to create, capture, organize, or distribute knowledge and ensure its accessibility for potential users.

Copious reasons have been specified for strategic knowledge transfer or collaboration in service firms, such as the desire to reduce competition and improved performance is frequently one of the major reasons. Hamel [12] argues that the wisdom intent of a firm is a key determinant of interfirm knowledge because the stronger the intention to learn, the higher the chance that knowledge will be transferred and the firm will learn from each other's or supplier's technology.

Learning intent is the desire and will of the focal firm to learn new knowledge from its supplier. Great body of empirical research supports the view that learning intent by the buyer increases inter-firm knowledge transfer. The supplier's motivation to transmit knowledge is an equally important factor [13].
Easterby-Smith et al., [14] argues that, the two are probable related, since when firms have a strong intention to learn new knowledge from the supplier this may dampen the enthusiasm of the supplier to provide such knowledge. Relatively little research has focused on how suppliers adapt when firms have a strong intention to learn their knowledge.

Omale [15] argues from a transaction cost economics perspective, suppliers often protect their knowledge in order to maintain their competitive advantage, and to decrease the likelihood of a buyer from using their knowledge in an opportunistic manner. A key task for the supplier is therefore to accumulate and protect its valuable knowledge and capabilities.

Within the perspective of a dyadic buyer-supplier relationship, Hamel, [12] and Simonin, [13] pointed out that, it is common for some partners to be less open and transparent with their knowledge. In other words, a duality frequently exists between the ability and the willingness of suppliers to transfer knowledge, which is likely to be an important determinant of the degree of inter-firm knowledge transfer [1].

Simonin [13] refers to this as the degree of supplier protectiveness. Types of protective mechanisms can range from formal contractual obligations, and patent protection, to using informal shielding practices aimed at protecting a supplier's core competencies.

\subsection{Characteristics of Knowledge}

Alongside the motivations of each party to transfer knowledge, an additional determinant is the ability of the focal firm to understand the factors that contribute to success, referred to as causal ambiguity [16]. Causal ambiguity is defined as a "lack of understanding of the logical linkages between actions and outcomes, inputs and outputs, and causes and effects that are related to technological or process know-how" [13]. Previous research has typically focused on the extent of causal ambiguity within firms, rather than between firms [13].

Knowledge transfer between firms is more difficult because causal ambiguity often makes it harder for firms to identify the Knowledge they wish to transfer from suppliers [11]. Also, when a supplier's competitive advantage is based on knowledge that is itself causally ambiguous, and then it is often difficult for buyer firms to receive inter-firm knowledge transfers [16]. Firms often find it difficult to absorb new knowledge, particularly when it originates from outside the firm. Absorptive capacity, defined as the ability to value, assimilate, and apply new knowledge, thus plays a central role in determining the extent of knowledge transfer from beyond the boundaries of the firm [17]. Empirical evidence highlights that firm possessing high levels of absorptive capacity are more likely to experience lower transfer costs and a faster speed of knowledge transfer [18].

Despite the theoretical importance attributed to absorptive capacity, comparatively little research focuses on its role within buyer-supplier relationships, and in particular when suppliers become involved in a firm's project [14]. Other key 
characteristic of knowledge are listed below without wasting time to explain in detail:

i. Non-depleting: unlike other resources that are managed because of their scarcity value, the more knowledge is used, the more is generated.

ii. Win-win sharing: The knowledge share with another person is retained by the first person.

iii. Chunkable and portable: it can be summarized, compressed or divided in manageable units for easier transfer and management

iv. Transferable: it can move from place to place; explicit knowledge, in particular, can easily be distributed via networks to many people.

v. Mobile: it tends to leak and diffuse, either as people move jobs, talk or through technical reproduction and transmission

vi. Substitutable: in many situations it can replace physical and other forms of resource; thus telecommunications reduces the need for travel.

These characteristics are more evident and do have values with explicit knowledge, however, its intangibility makes it difficult to identify and describe.

\section{Methodology}

Research methodology is a principle for solving a predicament, with precise mechanism like methods, techniques and research design etc. This study adopted a survey research design in assessing opinions and trends. The main tool for primary data collection was the questionnaire and interview guide. The questionnaire was designed for all the selected employees in the selected service firms. The questionnaire was based on a modified 5-point Likert Scale with the options, strongly agree, agreed, strongly disagreed, disagreed, No ideas, while interview was designed for key top management employees.

The data through which responses were given in the questionnaire was analyzed and interpreted with the use of percentages and students ' $t$ ' distributions test to analyses the data. This enable the researcher to draw conclusion based on the analysis.

\section{Data Presentation}

The best rational opinions still need to rely upon effective presentation of data, typically in the form of figures or tables. It is putting across collected information in a clear and concise manner. Presentation of data requires excellent arrangement of data and good communication skills and understanding of the target audience [15].

Therefore, data is presented in tabular form and consequently discussed briefly. A well-structured questionnaire was designed and distributed to the sampled employees of the selected service firms in Nigeria. The test of hypotheses was employed using chi-square statistical technique.

Two hundred and twenty five (225) questionnaires were prepared and dispersed but only two hundred and sixteen (216) were correctly filled and returned. Hence, the researcher based his analysis on the number that was correctly filled and returned. Table 1 shows the questionnaire distribution and collection schedule.

Table 1. Questionnaire Distribution and Collection Schedule.

\begin{tabular}{lllll}
\hline $\begin{array}{l}\text { No. } \\
\text { Distributed }\end{array}$ & $\begin{array}{l}\text { No. } \\
\text { returned }\end{array}$ & $\begin{array}{l}\text { No. } \\
\text { rejected }\end{array}$ & $\begin{array}{l}\text { No. } \\
\text { accepted }\end{array}$ & $\begin{array}{l}\text { No. not } \\
\text { return }\end{array}$ \\
\hline 225 & 216 & 2 & 216 & 7 \\
100 & $96 \%$ & $0.9 \%$ & $96 \%$ & $3.1 \%$ \\
\hline
\end{tabular}

Source: Researcher Field Survey, 2016

Table 1 depict that 225 questionnaire representing 100\% were prepared and distributed, 216 (Representing 96\%) out of 225 were correctly filled and returned, two questionnaires was wrongly filled while 7 questionnaires representing 3.1\% were not returned. The researcher based his analysis on the number that was correctly filled and returned which are 216.

\subsection{Analysis and Test of Hypotheses}

Table 2. Strategic inter-firms knowledge transfer impact positively on corporate venture performance.

\begin{tabular}{lll}
\hline Option & Responses & Percentages \\
\hline Strongly Agreed & 89 & 41.2 \\
Agreed & 96 & 44.4 \\
Strongly Disagreed & 16 & 7.4 \\
Disagreed & 11 & 5.1 \\
No idea & 4 & 1.8 \\
Total & 216 & 99.9 \\
\hline
\end{tabular}

Source: Researcher Field Survey, 2016

Table 2 shows that, 89 respondents representing 41.2\% strongly agreed with the fact that Strategic inter-firms knowledge transfer impact positively on corporate venture performance, 96 respondents representing $44.4 \%$ agreed with the statement, 16 respondents representing $7.4 \%$ strongly disagreed and $5.1 \%$ that is, 11 respondents disagreed while 4 respondents representing $1.8 \%$ failed to respond. This means that strategic inter-firms knowledge transfer impact positively on corporate venture performance.

Table 3. Corporate venture investment speeds up economic development of Nigeria.

\begin{tabular}{lll}
\hline Option & Responses & Percentages \\
\hline Strongly Agreed & 74 & 34.3 \\
Agreed & 137 & 63.4 \\
Strongly Disagreed & 3 & 1.4 \\
Disagreed & 2 & 0.9 \\
No idea & 0 & 0 \\
Total & 216 & 100 \\
\hline
\end{tabular}

Source: Researcher Field Survey, 2016

Table 3 reveals that 74 respondents representing $34.3 \%$ were of the view that corporate venture investment speeds up economic development of Nigeria, 137 respondents representing 63.4 agreed with the statement, $1.4 \%$ that is 3 respondents strongly disagreed, while 2 respondents 
representing $0.9 \%$ disagreed entirely. The analysis above indicates that corporate venture investment speeds up economic development of Nigeria.

\subsection{Testing of Hypotheses}

For ease of reference, the hypothesis as earlier presented is represented here.

\section{Hypothesis one}

Ho: Strategic inter-firms knowledge transfer does not impact positively on corporate venture performance

Hi: Strategic inter-firms knowledge transfer impact positively on corporate venture performance.

Table 4. Contingency Table $i$.

\begin{tabular}{lll}
\hline $\mathbf{X}$ & $\mathbf{X}-\mathbf{X}$ & $(\mathbf{X}-\mathbf{X}) \mathbf{2}$ \\
\hline 89 & 45.8 & 2097.64 \\
96 & 52.8 & 2787.84 \\
16 & -27.2 & 739.84 \\
11 & -32.2 & 1036.84 \\
4 & -39.2 & 1536.64 \\
$\Sigma \mathrm{X}=216$ & & $\sum(\mathrm{X}-\overline{\mathrm{X}})$ \\
$\mathrm{n}=\mathrm{s} \mathrm{X}=$ & $\frac{216}{5}$ & 8198.8 \\
$\mathrm{~S}=$ & $\frac{8198.8}{4}$ & $=43.2$ \\
$\mathrm{t}=$ & $\frac{\overline{\mathrm{X}}}{\sqrt{\frac{S^{2}}{n}}}$ & $=2049.7$ \\
$\mathrm{t}=$ & $\frac{43.2}{\sqrt{409.94}}$ & $\frac{43.2}{\sqrt{\frac{2049.7}{5}}}$ \\
& & $\frac{43.2}{20.25}=2.13$ \\
\hline
\end{tabular}

Tabulated t 0.05 for (5-1) that is, $\mathrm{d}$. $\mathrm{f}$ for two tailed test is 2.78 . Since calculated $t(2.13)$ is less than tabulated t 0.005 (2.78) for $4 \mathrm{~d}$., f Ho may be accepted at $5 \%$ of significance level and we may conclude that strategic inter-firms knowledge transfer positively impact on corporate venture performance.

Hypothesis two

Ho: Corporate venture investment does not speed up economic development of Nigeria.

Hi: Corporate venture investment speeds up economic development of Nigeria.

Table 5. Contingency Table ii.

\begin{tabular}{lll}
\hline $\mathbf{X}$ & $\mathrm{X}-\mathrm{X}$ & $(\mathbf{X}-\mathbf{X})^{\mathbf{2}}$ \\
\hline 74 & 30.8 & 948.64 \\
137 & 93.8 & 8798.44 \\
3 & -40.2 & 1616.04 \\
2 & -41.2 & 1697.44 \\
0 & -43.2 & 1866.24 \\
$\mathrm{n}=\mathrm{S} \mathrm{X}$ & $=\frac{216}{5}$ & $\Sigma(\mathrm{X}-\mathrm{X})^{2}=13310.76$ \\
$\mathrm{~S}^{2}=\frac{13310.76}{4}=$ & 3327.69 & $=43.2$ \\
$\mathrm{t}=$ & $\frac{\bar{X}}{\sqrt{\frac{S^{2}}{n}}}$ & 43.2 \\
$\mathrm{t}=$ & $\frac{43.2}{\sqrt{665.538}}$ & $\frac{43.2}{3327.69}$ \\
$\mathrm{t}=$ & 1.675 & $\sqrt{\frac{33}{5}}$ \\
\hline
\end{tabular}

Tabulated t 0.005 for (5-1) that is $\mathrm{d}$. $\mathrm{f}$ for two tailed test is 2.78. Since calculated $\mathrm{t}(1.675)$ is less than tabulated $\mathrm{t} 0.005$ (2.78) for $4 \mathrm{~d}$. f, Ho may be accepted at $5 \%$ of significance and we may conclude that corporate venture investment speeds up economic development of Nigeria.

\section{Summary of Findings}

The following findings were arrived at after due consideration of data analysis.

1. Finding indicates that, strategic inter-firms knowledge transfer impact positively on corporate venture performance. It enables one firm to gain access to key knowledge based capabilities of another without necessarily acquiring that capability.

2. Corporate venture investment speeds up economic development of Nigeria as knowledge transfer promotes the sharing of thoughts, experiences, skills and learning's to assist and control individual or group decision making in an organization.

3. Finally, finding review that knowledge dispersed in most cases are not properly evaluated and monitored to determine its authenticity.

\section{Conclusion}

Knowledge transfer activities cannot be underestimated if firms must achieve its objective. Knowledge transfer is highly exceptional, demanding, and changing requirements that need to be understood by firms to drive decision making and effective problem solving. The primary objective of conducting knowledge transfer activities is to retain and manage various knowledge types that can be used to inform decision making and problem solving. Therefore one can certainly conclude that, ability to access the right knowledge at the right time enables long term sustainability and development of the firms. Knowledge transfer is an activity that enables organizations to determine the extent of knowledge acquired by employees and those who needs to know basic things required, and how to transfer that knowledge effectively for the development of firms by meeting specific needs.

\section{Recommendations}

Firms should identify the knowledge holders within their organization and motivating them to share their knowledge to enhance it investment and performance.

Secondly, firms should designing profit sharing mechanism to facilitate trust and subsequent transfer of such knowledge to accelerate it development and investment.

Thirdly, firms should monitor and evaluate the authenticity of knowledge dispersed in other to build the confidence of all stake holders in the business. 


\section{References}

[1] Mowery, D. C.; Joanne, E. O. \& Brian, S. S. (1996). Strategic Alliances and Inter-firm Knowledge Transfer. Strategic Management Journal, Vol. 17, 77-91.

[2] Porter, M. E. \& Fuller, M. B. (1986). Coalitions and global strategy. In M. E. Porter (ed.), Competition in Global Industries. Boston: Harvard Business School Press, 315-344.

[3] Hagedoorn, J. (1993). Understanding the rationale of strategic technology partnering: Inter-organizational modes of cooperation and sectoral differences, Strategic Management Journal, Vol. 14 (5), 371-385.

[4] Powell, W. \& Brantley, P. (1992). Competitive cooperation in biotechnology: Learning through networks? In N. Nohria and R. Eccles (eds.), Networks and Organizations: Structure. Form and Action. Boston, MA: Harvard Business School Press, 365-394.

[5] Tansey, P., Meng, X. and Cleland, D. (2013) A critical review of response strategies adopted by construction companies during an economic recession, in Smith, S. D. and AhiagaDagbui, D. D. (eds) Proceedings 29th Annual ARCOM Conference, 2-4 September, Reading, UK, pp. 679-89.

[6] Thisday Live Newspaper. (2016,\} 'As Nestle Encounters New Challenges. August $10 . \quad$ Retrieved from: http://www.thisdaylive.com/index.php/2016/08/10/as-nestleencounters-new-challenges/

[7] Argote, L. \& Ingram, P. (2000). "Knowledge transfer: A Basis for Competitive Advantage in Firms". Organizational Behavior and Human Decision Processes, 82 (1). 150-169.

[8] Pahnke, E. McDonald, R. Dan Wang, and Benjamin Hallen. (2014) Exposed: Venture capital, competitor ties, and entrepreneurial innovation. Academy of Management Journal

[9] Helmers, C, Manasa, P, and Raghavendra. R (2013). Do board interlocks increase innovation? evidence from natural experiments in india. Working Paper, 2013.

[10] Roberta D and Nina Y.(2015) Venture Capital and Knowledge Transfer Toulouse School of Economics Tulane University

[11] Grant, R. M. \& Baden-Fuller, C. (1995). A knowledge based theory of inter-firm collaboration, Best Academy of Management, pp. 17-21.

[12] Hamel, G. (1991). Competition for competence and interpartner learning within international strategic alliances. Strategic Management Journal, Summer Special Issue, Vol. $12,83-103$.

[13] Simonin, B. L. (1999). "Ambiguity and the process of knowledge transfer in strategic alliances". Strategic Management Journal, Vol. 20 (7), 595-623.

[14] Ettlie, J. E. \& Pavlou, P. A. (2006). "Technology-based new product development partnerships". Decision Sciences, Vol. 37 (2), 117-47.

[15] Omale, S. A. (2015). Impact assessment of Interorganizational Trust on Virtual Organizations Performance in Nigerian Service Firms. Cscanadian Journal of Business \& Management, 12 (1), 6-19.

[16] Reed, R. \& DeFillippi, R. J. (1990). "Causal ambiguity, barriers to imitation and sustainable competitive advantage". Academy of Management Review, Vol. 15 (1), 88-102.

[17] Cohen, W. M. \& Levinthal, D. A. (1990), “Absorptive capacity: a new perspective on learning and innovation". Administrative Science Quarterly, Vol. 35, 128-52.

[18] Cummings, J. L. \& Teng, B. S. (2003). "Transferring R\&D knowledge: the key factors affecting Knowledge transfer success", Journal of Engineering \& Technology Management, Vol. 20, 39-68. 